\title{
Strategi untuk Mengatasi Permasalahan Wanita Rawan Sosial Ekonomi (WRSE)
}

\author{
Alia Fajarwati ${ }^{1}$, Eva Latifah Puspita Sari ${ }^{2}$ dan Nirania Galuh Putrie Soewarno ${ }^{3}$
}

\author{
Fakultas Geografi, Universitas Gadjah Mada, Indonesia ${ }^{123}$ \\ Email Koresponden:aliafajar@ugm.ac.id \\ Diterima: 28 Desember 2016 /Disetujui:18 Februari 2017 / Publikasi online: 31 Maret 2017
(c) 2017 Fakultas Geografi UGM dan Ikatan Geograf Indonesia (IGI)
}

\begin{abstract}
Abstrak Di Indonesia, dalam upaya untuk mengentaskan kemiskinan, Dinas Sosial mengelompokkan penduduk yang menjadi target, yaitu kelompok penduduk Penyandang Masalah Kesejahteraan Sosial (PMKS). Menurut Dinas Sosial, setidaknya terdapat 22 definisi operasional dan karakteristik dari masing-masing jenis PMKS, salah satunya adalah Wanita Rawan Sosial Ekonomi (WRSE). Metode deskriptif baik kuantitatif maupun kualitatif digunakan dalam studi ini. Metode yang digunakan dalam studi ini adalah deskriptif baik dengan pendekatan kualitatif maupuan pendekatan kuantitatif. Lokasi penelitian adalah di Kabupaten Temanggung. Survei lapangan dilaksanakan di Desa Tepusen, Kecamatan Kaloran. Metode sensus digunakan dalam studi ini, yaitu dengan mewawancarai seluruh WRSE yang ada di Desa Tepusen. Hasil studi menunujukkan: 1) jumlah WRSE terbesar di Kabupaten Temanggung menurut data statistik adalah di Kecamatan Temanggung yaitu sebanyak 691 WRSE dan terkecil di Kecamatan Bulu yaitu sebayak 22 WRSE; 2) faktor-faktor yang menyebabkan wanita menjadi WRSE di desa ini adalah perceraian/kematian suami, tingkat pendidikan rendah, pekerjaan dengan gaji rendah; 3) upaya-upaya yang telah dilakukan Dinsos untuk mengatasi WRSE yaitu dana ternak, pelatihan pembuatan kue dan pelatihan sulam pita; 4) faktor-faktor penghambat dalam upaya pengentasan WRSE adalah terbatasnya waktu senggang, tingkat pendidikan rendah, usia, jumlah tanggungan, terbatasnya akses finansial; dan 5) strategi yang dapat direkomendasikan untuk mengentaskan WRSE dari kemiskinan: akses ke pendidikan formal, pelatihan untuk meningkatkan kapabilitas, bantuan dana untuk penghidupan dan anak-anak WRSE, membuka akses pada keuangan mikro, pendampingan spiritual/psikologis, memperkuat jaringan pendukung WRSE dan pelibatan WRSE dalam perencanaan maupun program pengentasan kemiskinan.
\end{abstract}

Kata kunci: kemiskinan, pengentasan kemiskinan, PMKS, WRSE

\begin{abstract}
In Indonesia, as an effort to a poverty alleviation, Department of Social Welfare in Indonesia has a program with the target groups such as 'Penyandang Masalah Kesejahteraan Sosial (PMKS)- The Social Welfare Problems People'. There are at least 22 operational definitions and characteristic from each category of PMKS. One of group of women who included in this group is 'Wanita Rawan Sosial Ekonomi (WRSE)-Economic Social Prone Women-group. This study uses descriptive method, both with quantitative and qualitative approach. The research location is in the District of Temanggung. The field survey was conducted in Tepusen Village, Kaloran District. Census method used in this study, which by interviewing the entire WRSE in the Tepusen Village. The study results show: 1) factors that cause women to be WRSE in this village is divorcement or the husband's death, low education level, low-salary occuption; 2) the efforts that have been made to overcome WRSE's poverty by Dinsos namely livestock funds, cullinary training and training of stitching ribbon; 3) the factors inhibiting reduction WRSE is limited leisure time, low education level, age, number of dependents, limited access to finance; and 4) strategies can be recommended to alleviate WRSE of poverty are opening access to formal education, holding trainings to improve capability, funding for WRSE's livelihood and WRSE's children, opening access to microfinance, mentoring WRSE'S spiritual / psychological, strengthening the WRSE's supporters network and involving WRSE in WRSE's poverty alleviation planning or program.
\end{abstract}

Keywords: poverty, poverty alleviation, PMKS, WRSE

\section{PENDAHULUAN}

Geografi pembangunan adalah cabang ilmu geografi yang mengacu pada standar hidup dan kualitas hidup penduduk manusia. Bebbington (2003) menyarankan bahwa lokasi (place) merupakan salah satu konsep inti untuk geografi pembangunan, bersama dengan pengertian tentang kehidupan (livelihood), skala (scale) dan jaringan (network). Dalam studi ini, pembangunan diartikan sebagai proses perubahan yang mempengaruhi kehidupan masyarakat yang mungkin melibatkan peningkatan kualitas hidup/ kesejahteraan seperti yang dirasakan oleh masyarakat yang mengalami perubahan.
Kesejahteraan sosial adalah bagian tak terpisahkan dari cita-cita kemerdekaan dan merupakan tujuan pembangunan negara. Oleh karena itu UUD 1945 mengamanatkan tanggung jawab pemerintah dalam pembangunan kesejahteraan sosial. Dalam upaya pengentasan kemiskinan, Dinas Sosial mengelompokkan penduduk yang menjadi target pengentasan kemiskinan, yaitu kelompok penduduk Penyandang Masalah Kesejahteraan Sosial (PMKS). PMKS adalah seseorang, keluarga atau kelompok masyarakat yang karena suatu hambatan, kesulitan atau gangguan tidak dapat melaksanakan fungsi sosialnya, sehingga tidak dapat terpenuhi kebutuhan hidupnya 
baik jasmani, rohani dan sosial secara memadai dan wajar. Hambatan, kesulitan dan gangguan tersebut dapat berupa kemiskinan, keterlantaran, kecacatan, ketunaan sosial, keterbelakangan, keterasingan/keterpencilan dan perubahan lingkungan (secara mendadak) yang kurang mendukung, seperti terjadinya bencana. Menurut Kementrian Sosial, setidaknya terdapat 22 definisi operasional dan karakteristik dari masingmasing jenis PMKS. Dari ke-22 jenis PMKS tersebut, salah satu kategorinya adalah perempuan, yaitu Wanita Rawan Sosial Ekonomi (WRSE).

Kesejahteraan wanita wajib menjadi agenda penting dalam program pengentasan kemiskinan karena kesejahteraan wanita pada umumnya bisa mencerminkan kesejahteraan keluarga dan dapat menjadi jaminan bagi kesejahteraan golongan PMKS lainnya, yaitu anak-anak, lansia, dan anggota keluarga yang menderita penyakit. Hal tersebut terkait dengan perananan reproduktif yang melekat pada kaum perempuan. Peranan reproduktif adalah peranan yang berhubungan dengan tanggung jawab pengasuhan anak dan tugas-tugas domestik yang dibutuhkan untuk menjamin pemeliharaan dan reproduksi tenaga kerja yang menyangkut kelangsungan keluarga (Moser, 1989 dalam Fausia dan Prasetyaningsih, 2005), contohnya: memasak, memelihara rumah, memelihara dan mengasuh anak dan anggota keluarga lainnya. Lebih lanjut Suman (2007) menggambarkannya sebagai sebuah aliran kecil yang memasuki arus besar welfare economics yang menyatakan bahwa tingkat keberdayaan kaum perempuan harus dipertimbangkan dalam upaya menyejahterakan masyarakat secara keseluruhan. Di Indonesia terlebih pada masyarakat perdesaan argumen tersebut dapat dipahami karena: 1) perempuan, dari sudut pandang budaya lokal dalam masyarakat pertanian, lebih banyak tinggal di rumah dan memiliki banyak waktu luang; 2) perempuan lebih banyak bekerja di sektor domestik sehingga mereka lebih banyak mengetahui kebutuhan nutrisi dan kesehatan bagi keluarganya; 3) adanya kendala (constraint) bagi perempuan untuk mengakses kredit kecil (microfinance) untuk usaha. Banyak laporan yang menyatakan bahwa perempuan sering menjadi market target dari rentenir (moneylenders), tukang gadai (pawnbrokers), dan penjual barang-barang kebutuhan rumah tangga (seperti: sandang dan peralatan dapur) dengan fasilitas kredit.

Di Indonesia, dalam upaya untuk mengentaskan kemiskinan, Dinas Sosial mengelompokkan penduduk yang menjadi target, yaitu kelompok penduduk Penyandang Masalah Kesejahteraan Sosial (PMKS). PMKS adalah seseorang, keluarga atau kelompok masyarakat yang karena suatu hambatan, kesulitan atau gangguan tidak dapat melaksanakan fungsi sosialnya, sehingga tidak dapat terpenuhi kebutuhan hidupnya baik jasmani, rohani dan sosial secara memadai dan wajar. Hambatan, kesulitan dan gangguan tersebut dapat berupa kemiskinan, keterlantaran, kecacatan, ketunaan sosial, keterbelakangan, keterasingan/keterpencilan dan perubahan lingkungan (secara mendadak) yang kurang mendukung, seperti terjadinya bencana. Menurut Dinas Sosial, setidaknya terdapat 22 definisi operasional dan karakteristik dari masing-masing jenis PMKS, salah satunya adalah Wanita Rawan Sosial Ekonomi (WRSE). WRSE adalah wanita baik gadis maupun janda yang merupakan kepala keluarga. Harini dan Listyaningsing (2000) menjelaskan wanita kepala rumah tangga adalah wanita yang dianggap bertanggung jawab terhadap rumah tangganya, yaitu: (1) wanita tidak kawin yaitu wanita yang tidak terikat dengan perkawinan dan bertanggung jawab terhadap rumah tangganya; (2) wanita kawin yaitu wanita yang terikat dalam perkawinan tetapi tempat tinggalnya terpisah dengan suami sehingga wanita tersebut mengepalai rumah tangganya; (3) wanita cerai hidup atau cerai mati dan belum menikah lagi dan tidak kembali ke keluarga yang melahirkan atau mertua. Secara lebih spesifik, menurut Dinas Sosial (2015) WRSE adalah seseorang Wanita Dewasa yang belum menikah atau janda yang tidak mempunyai penghasilan cukup untuk dapat memenuhi kebutuhan pokok sehari-hari dengan ciri-ciri Wanita Dewasa, belum menikah (adalah wanita anak fakir miskin) atau janda (adalah wanita sebagai Kepala Keluarga), berusia $18-<6 \quad 0$ tahun dan penghasilan tidak memenuhi kebutuhan pokok sehari-hari.

Rumah tangga yang dikepalai wanita biasanya miskin karena pendidikannya rendah; akses terbatas terhadap: pekerjaan, pelayanan sosial, sumber produksi, modal, kredit dan tanah; serta memiliki sedikit jaringan kekerabatan yang mendukungnya (Clark, 1986 dalam Harini dan Listyaningsing, 2000). Terkonsentrasinya kemiskinan diantara perempuan, terutama perempuan yang menjadi kepala rumah tangga terkait dengan rendahnya pendapatan mereka dibandingkan dengan laki-laki disebut Dubois (2005) sebagai feminisasi kemiskinan (feminization of poverty).

Idris dan Selvaratnam (2012) menyebutkan bahwa insiden kemiskinan baik secara relatif atau absolut adalah tinggi di kalangan wanita terutama bagi wanita yang menjadi kepala rumah tangga. Bagi wanita yang bercerai hidup atau mati, mereka bisa menjadi miskin serta merta jika terpaksa menanggung anak tanpa nafkah atau harta yang ditinggalkan. Kemiskinan di kalangan ibu tunggal antara aspek yang menjadi perhatian pihak pemerintah dalam perumusan strategi pengentasan kemiskinan. Kemiskinan di kalangan ibu tunggal harus diberi perhatian mengingat dia dapat memberi implikasi sosial jika tidak ditangani secara efektif.

Namun demikian, untuk mengurangi tingkat kemiskinan dan jumlah wanita miskin tidak dapat dicapai hanya dengan program ekonomi karena karena adanya nilai-nilai sosial seperti peranan reproduktif yang melekat pada kaum perempuan (misalnya: merawat anak, pekerjaan rumah tangga). 
Oleh sebab itu, dalam kaitannya dengan upaya untuk memahami dan mengentaskan perempuan kepala keluarga khususnya WRSE dari kemiskinan, studi ini memiliki tujuan untuk menggali faktor-faktor yang menyebabkan wanita menjadi WRSE, mengetahui upaya-upaya untuk mengatasi WRSE, mengidentifikasi kendala untuk mengatasinya, dan merekomendasikan strategi untuk mengentaskan mereka dari kemiskinan.

Penelitian ini dihararapkan menambah referensi bagi penelitian mengenai feminisasi kemiskinan maupun pengentasan kemiskinan perempuan khususnya WRSE yang belum pernah dilakukan sebelumnya.

\section{METODE PENELITIAN}

Penelitian ini menggunakan metode penelitian deskriptif baik dengan pendekatan kualitatif maupuan pendekatan kuantitatif. Metode penelitian deskriptif merupakan metode penelitian untuk menggambarkan fenomena sosial yaitu WRSE. Lokasi penelitian adalah di Kabupaten Temanggung, Provinsi Jawa Tengah. Kabupaten ini berbatasan dengan Kabupaten Kendal di utara, Kabupaten Semarang di timur, Kabupaten Magelang di selatan, serta Kabupaten Wonosobo di barat (Gambar 1).

Survei lapangan dilaksanakan di Desa Tepusen, Kecamatan Kaloran, Kabupaten Temanggung untuk mendapatkan data primer maupun sekunder mengenai faktor-faktor yang menyebabkan wanita menjadi WRSE; faktor-faktor penghambat dalam upaya pengentasan WRSE. Pada level kabupaten-desa juga akan digali informasi mengenai upaya-upaya yang telah dilakukan untuk mengatasi WRSE baik yang dilakukan oleh pemerintah maupun pihak-pihak lain.

Metode sensus digunakan dalam penelitian ini, yaitu dengan mewawancarai seluruh WRSE yang ada di Desa Tepusen. Dari list WRSE tahun 2015 diperoleh keterangan ada 40 WRSE yang ada di desa ini. Dengan dibantu perangkat desa, dari ke 40 WRSE tersebut kemudian tersortir menjadi 20 WRSE karena berbagai alasan: data dobel, WRSE sudah pindah rumah tidak lagi di desa tersebut, WRSE telah meninggal atau telah menikah lagi.

\section{HASIL DAN PEMBAHASAN}

Fokus penelitian ini adalah menggali faktor-faktor yang menyebabkan wanita menjadi WRSE, mengetahui upaya-upaya untuk mengatasi WRSE, mengidentifikasi kendala untuk mengatasinya, dan merekomendasikan strategi untuk mengentaskan mereka dari kemiskinan. Seluruh WRSE di desa ini berada pada rentang usia produktif, yang termuda berusia 31 tahun dan yang tertua berusia 63 tahun; mengecap pendidikan tertinggi Sekolah Dasar (Gambar 2); jika bekerja memiliki pekerjaan dengan upah rendah (Gambar 3).

Faktor pertama penyebab perempuan di Desa Tepusen menjadi WRSE adalah karena mereka harus menjadi kepala keluarga (tulang punggung) atau ibu tunggal karena sesuatu hal. Adapun seluruh WRSE di desa ini adalah janda, tidak ditemukan kasus gadis yang menjadi tulang punggung keluarganya. Hasil penelitian menunjukkan penyebab mereka menjadi janda adalah karena suami meninggal (80\%) atau karena diceraikan (20\%). Kasus perceraian sebagai penyebab WRSE menjadi janda di desa ini ditemukan pada WRSE berusia antara 50 - 60 tahun. Rentang usia WRSE di desa ini menjadi janda adalah pada waktu mereka berusia antara 28 - 58 tahun dan sejak saat itu mereka terpaksa menjadi kepala keluarga. Idris dan Selvaratnam (2012) menyebutkan bahwa insiden kemiskinan baik secara relatif atau absolut adalah tinggi di kalangan wanita terutama bagi wanita yang menjadi kepala rumah tangga. Bahkan salah satu kesimpulan Evans (1991) dalam Idris dan Selvaratnam (2012) adalah bahwa kemiskinan perempuan lebih besar jika didistribusikan menurut kategori dari menikah menjadi tidak menikah daripada didistribusikan menurut jenis kelamin.

Hal tersebut dapat dijelaskan dengan: bagi wanita yang bercerai hidup atau mati, mereka bisa serta merta menjadi miskin atau menjadi lebih miskin dari sebelumnya (pada saat masih memiliki suami) jika terpaksa menanggung anak tanpa nafkah atau harta yang ditinggalkan. Berikut kesan salah satu WRSE pasca suaminya meninggal:

"Sedih, harus menanggung banyak hutang, dan masih harus menghidupi anak dan membiayai sekolahnya." (WRSE/19, 2016)

Ungkapan kesedihan dan kesulitan hidup setelah menjadi janda tersebut dirasakan oleh 90\% WRSE di desa ini. Hanya 10\% yang menyatakan pasrah meskipun hidupnya kekurangan.

Faktor kedua yang menyebabkan perempuan menjadi WRSE di desa ini adalah tingkat pendidikan mereka. Gambar 2 menunjukkan WRSE di Desa Tepusen maksimal hanya mengecap pendidikan sampai sekolah dasar. Sebanyak 60\% WRSE di desa ini tamat SD dan sisanya sempat mengecap pendidikan SD namun tidak sampai lulus. Hal yang menarik dari tingkat pendidikan WRSE di desa ini adalah bahwa WRSE berusia di bawah 50 tahun dan di atas 60 tahun semuanya lulus SD, sedangkan seluruh WRSE yang tidak tamat SD berada pada rentang usia 50-60 tahun. Alasan yang dikemukakan oleh WRSE adalah karena tidak ada biaya untuk melanjutkan sekolah atau karena menikah. Malherbe (1932 dalam Christie dan Gordon, 1992) menambahkan kegagalan mereka menyelesaikan sekolah juga bisa diakibatkan oleh efek dari kekurangan gizi, kemiskinan, kesehatan yang buruk, dan cacat fisik dan mental yang kemudian mengakibatkan prestasi sekolah yang buruk, kegagalan dan meninggalkan sekolah sebelum lulus.

Faktor ketiga yang menyebabkan wanita di desa ini menjadi WRSE adalah jenis pekerjaan yang mereka miliki. Berbeda dengan perempuan kepala keluarga di Kota Yogyakarta yang memilih untuk membuka 


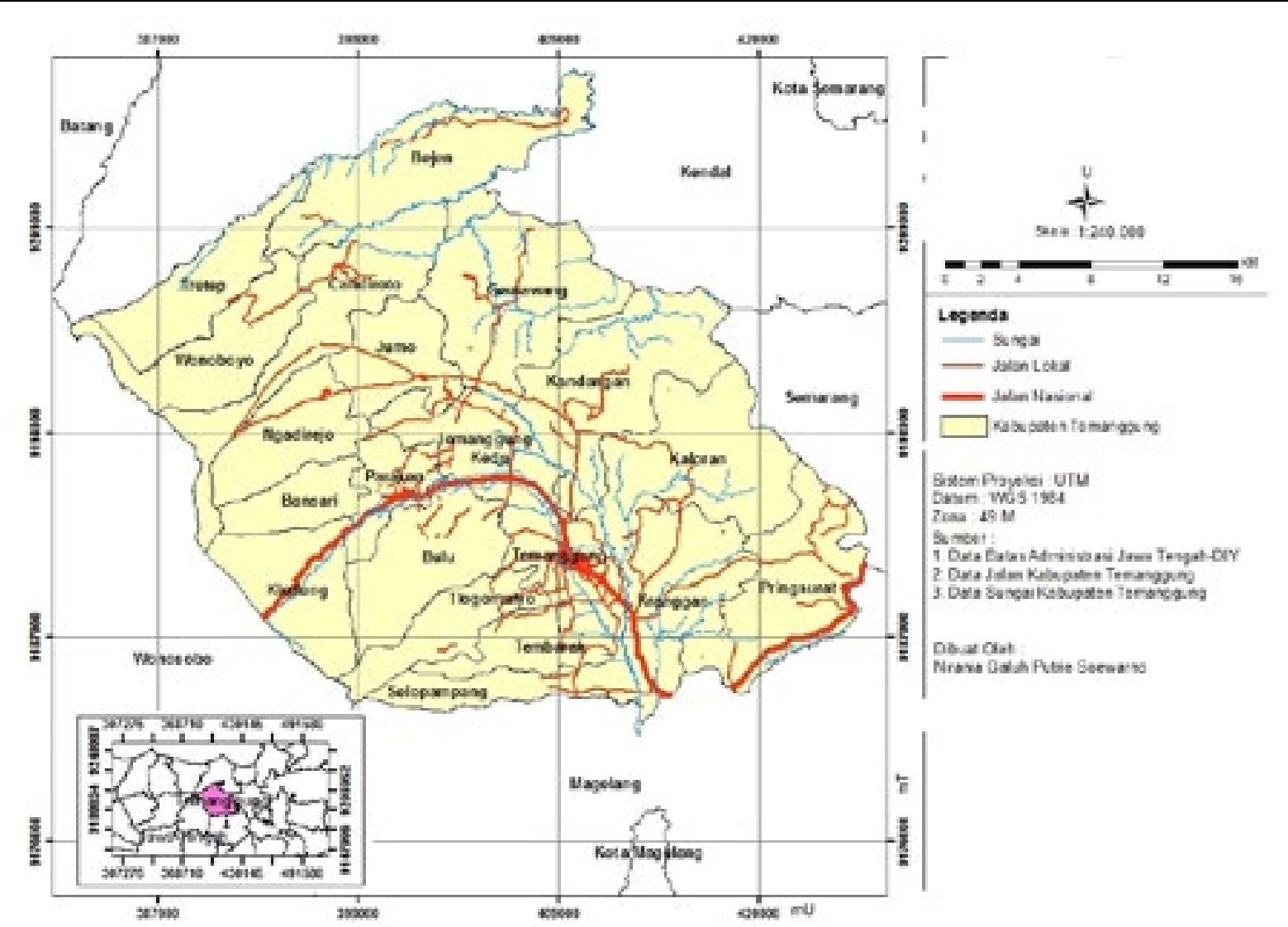

Sumber : Data Sekunder, 2016

Gambar 1. Peta Administrasi Kabupaten Temanggung

warung, dan perempuan pinggiran Kota Yogyakarta yang memilih usaha wiraswasta dan minta bantuan ke anggota keluarga sebagai strategi mencukupi kebutuhan sehari-hari (Harini dan Listyaningsih, 2000), Gambar 3 menunjukkan bahwa pekerjaan WRSE di desa ini adalah buruh tani (20\%), butuh serabutan (20\%), petani (15\%), penjual makanan/sayur (15\%), Asisten Rumah Tangga (10\% yang seluruhnya merupakan jenis pekerjaan yang memberikan tingkat kesejahteraan rendah. 20\% sisanya merupakan Ibu Rumah Tangga (10\%) dan tidak bekerja (10\%). Keputusan untuk tidak bekerja atau menjadi Ibu Rumah Tangga ditemukan pada ketiga klasifikasi WRSE. Namun demikian jika dianalisa lebih lanjut, WRSE yang tidak melakukan aktifitas produktif tersebut disebabkan karena tidak lagi memiliki tanggungan dan hidup mereka dibiayai oleh anak atau saudara.

Hinks (2002 dalam Flato et.al., 2016) menjelaskan hal tersebut sebagai dampak dari terbatasnya kesempatan dan sumberdaya di sektor lapangan pekerjaan formal, mengakibatkan wanita menduduki pekerjaan dengan upah rendah dan kondisi kerja yang buruk, seperti Asisten Rumah Tangga (ART). Nihayah (2015) menambahkan, bagi masyarakat miskin yang telah memasuki usia kerja, mayoritas dari mereka berpendidikan rendah, ketrampilan yang minim serta modal yang sedikit (Nihayah, 2015).

Seperti halnya yang terjadi di Afrika Selatan, secara historis, hal tersebut juga berkaitan dengan terbatasnya akses ke pendidikan, runtuhnya pekerjaan formal mendorong perempuan menjadi kurang dibayar, terdorong pada sektor informal yang sangat tidak stabil dan kurang memiliki akses terhadap sumberdaya seperti perumahan dan pelayanan kesehatan, sebagai penjelasan Gilbert \& Walker (2002 dalam Flato et.al., 2016) atas kerugian ekonomi dari rumah tangga yang dikepalai oleh perempuan. Padahal pada kenyataannya, perempuan tani menghabiskan waktu $21 \%$ lebih banyak pada aktifitas produktif dibandingkan dengan pria (Budlender, 2005).

Upaya-upaya yang telah dilakukan untuk mengatasi WRSE selama ini telah dilakukan pendataan PMKS di Kabupaten Temanggung dengan out put data by name dan by address PMKS di tiap-tiap desa yang difasilitasi oleh Dinas Sosial. Dari hasil indepth interview yang dilakukan dengan Kepala Bidang Asistensi Sosial, Dinas Sosial yang menangani WRSE, secara garis besar terdapat 3 jenis program kegiatan yang telah/akan dilakukan, yaitu (1) Hibah dana ternak (kambing), (2) Pelatihan membuat kue (3)Pelatihan sulam pita.

Pada tahun-tahun sebelumnya pernah ada upaya memberikan bantuan modal usaha untuk WRSE di kabupaten ini, namun upaya tersebut kurang berhasil sehingga digantikan dengan pemberian hibah dana ternak karena dinilai ternak mudah dalam perawatannya. Hasilnya pun jelas dan dapat digunakan 


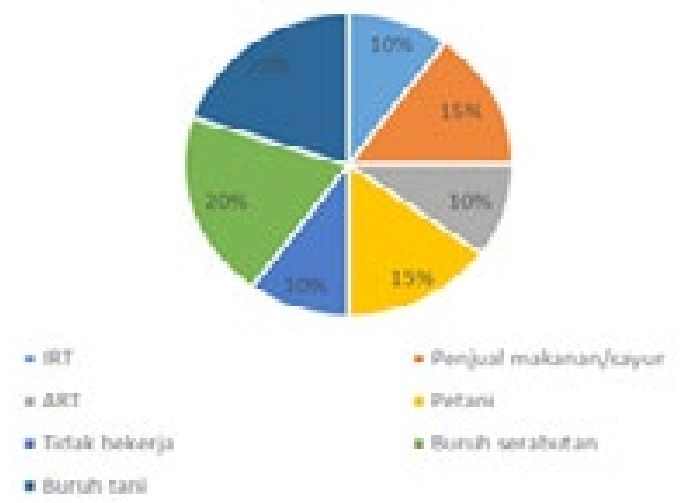

Sumber: Data primer, 2016

Gambar 2. Tingkat pendidikan WRSE di Desa Tepusen sebagai tabungan.

"Kami pernah memberikan bantuan modal usaha, hasilnya tidak terlihat. Banyak yang kemudian gulung tikar karena tidak telaten atau modalnya habis untuk kebutuhan sehari-hari." (Kepala Bidang Asistensi Sosial, Dinas Sosial)

Hasil wawancara dengan WRSE di Desa Tepusen menunjukkan hanya 10\% WRSE yang ada di desa ini menyatakan telah mendapat bantuan berupa pelatihan membuat kue, dan dana untuk ternak (ayam) \& dana bansos dari Dinas Sosial terkait pengentasan WRSE. Selebihnya mendapat bantuan namun tidak terkait langsung dengan program untuk WRSE seperti raskin, Bantuan Langsung Tunai (BLT), bantuan dana BBM, bantuan kesehatan berupa Jamkesmas, dan $\mathrm{PKH}$ (Gambar 4).

Dari Gambar 4 terlihat bahwa pada umumnya WRSE di desa ini (55\%) mendapatkan bantuan berupa BLT dan raskin; sudah 90\% WRSE terjangkau oleh raskin. Namun demikian, WRSE di desa ini mengaku bahwa program-program bantuan tersebut tidak seluruhnya rutin mereka terima atau bahkan tidak lagi mereka terima.

Jika dianalisa lebih lanjut, ketiga program pengentasan WRSE dari Dinas Sosial tersebut bertujuan untuk memberikan modal finansial/ketrampilan untuk meningkatkan penghidupan WRSE. Program pelatihan untuk meningkatkan kapabilitas penting untuk WRSE karena Buvinic (1997) menyatakan bahwa ada banyak bukti bahwa perempuan di negaranegara berkembang tampaknya menanggung beban "kemiskinan berdasarkan kapabilitas".

Evaluasi dari program pengentasan kemiskinan WRSE yang telah dilakukan oleh Dinas Sosial adalah program pendampingan untuk meningkatkan kapabilitas WRSE di Desa Tepusen selain yang terkait dengan peningkatan perekonomian WRSE seharusnya juga dilakukan, mengingat mengurangi tingkat kemiskinan dan jumlah wanita miskin tidak dapat dicapai hanya dengan program yang berorientasi ekonomi.

Analisa faktor-faktor penghambat dalam upaya pengentasan WRSE, menurut Pedoman Umum

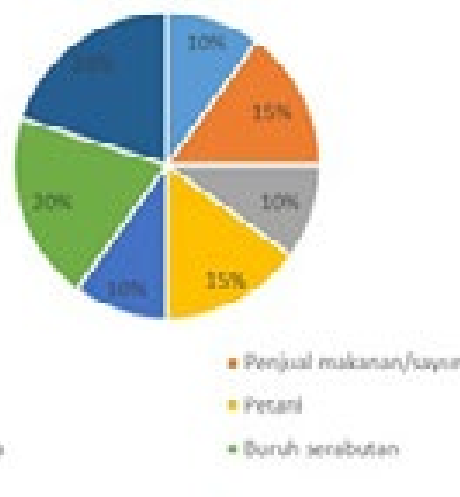

Sumber: Data Primer, 2016

Gambar 3. Pekerjaan WRSE di Desa Tepusen

Pemberdayaan Keluarga (2005) WRSE adalah seorang wanita yang karena faktor kemiskinan, keterbelakangan dan kebodohannya mengalami gangguan fungsional dalam kehidupan sosial dan atau ekonominya sehingga yang bersangkutan mengalami kesulitan dalam menjalankan peranan sosialnya. Dalam menjalani kehidupannya, WRSE tentu memperoleh hambatan maupun dukungan dari berbagai pihak. Hambatan tersebut dapat berasal dari luar maupun dari dalam diri WRSE. Pentingnya memahami hambatan WRSE dalam kehidupan mereka sehari-hari adalah untuk menganalisa program pengentasan kemiskinan yang sesuai dengan kemampuan maupun kondisi mereka.

Hambatan yang dijumpai WRSE dalam kehidupannya, menurut hasil interview dengan WRSE di Desa Tepusen, sebagian besar WRSE di desa tersebut menyatakan tidak mendapatkan hambatan (60\%) dalam menjalani kehidupannya, sedangkan 40\% menyatakan bahwa ada berbagai pihak yang menghambat kehidupan mereka (Gambar 5). Secara garis besar hambatan-hambatan tersebut berasal dari anak, pemerintah dan tetangga.

Permasalahan yang dihadapi perempuan bukan hanya ketidakadilan dalam mengakses sistem sumber pada tatanan meso dan makro, akan tetapi perlakuan ketidakadilan yang diperoleh dalam keluarganya sendiri. Namun bukan hambatan yang berasal dari keluarga semacam itu yang dirasakan oleh WRSE di Desa Tepusen. Hambatan yang berasal dari keluarga merupakan hambatan dari anak yang berupa anak memiliki penyakit mental, anak memiliki kebutuhan sendiri sehingga belum dapat membantu penghidupan ibunya, atau anak belum memiliki pekerjaan yang mapan sehingga masih membutuhkan sokongan dari ibunya.

Sementara WRSE di desa ini menilai hambatan yang berasal dari pemerintah dikarenakan pemerintah belum memberikan bantuan, bantuan yang diberikan pemerintah dinilai belum cukup, pemerintah belum memberikan akses pada berbagai bantuan misalnya BLT, pemerintah tidak rutin memberikan bantuan, dan pemerintah dinilai terkadang salah menentukan sasaran penerima bantuan. Adapun 10\% WRSE 


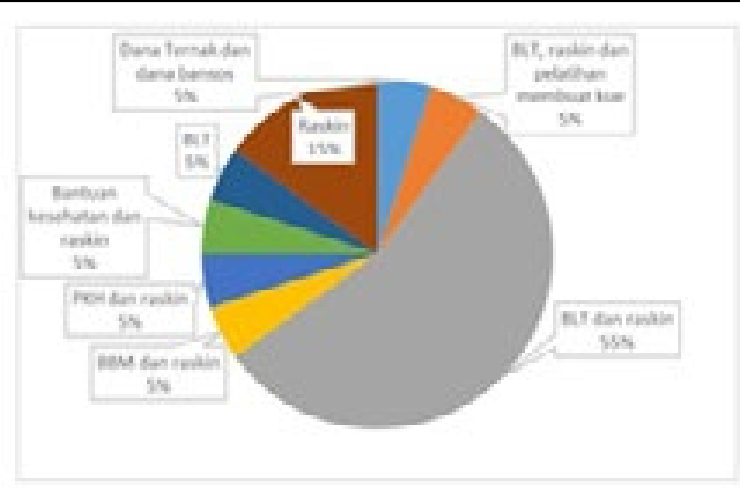

Sumber: Data Primer, 2016

Gambar 4. Program/Bantuan yang Diterima Oleh WRSE di Desa Tepusen

juga menganggap bahwa hambatan juga berasal dari tetangga karena tidak mau membantu dalam bentuk finansial atau bantuan lainnya.

Faktor penghambat dalam upaya-upaya pengentasan WRSE. Upaya pengentasan kemiskinan melalui pemberian modal usaha (hibah ternak) dan program pelatihan oleh Dinas Sosial ternyata berbeda dengan program/bantuan yang diinginkan/ diusulkan oleh WRSE di Desa Tepusen. Gambar 6 memperlihatkan hanya 10\% WRSE di desa ini yang menginginkan bantuan berupa program pelatihan usaha dan pemberian modal usaha, dan hanya $10 \%$ WRSE yang menginginkan pemberian modal usaha.

Dari Gambar 6 terlihat bahwa sebagian besar WRSE (55\%) menginginkan program/bantuan yang bersifat murni bantuan langsung berupa renovasi rumah atau bantuan dana untuk menopang kehidupan mereka sehari-hari. Mereka menginginkan bantuan yang langsung bisa mereka rasakan manfaatnya, bukan pelatihan yang sebenarnya dapat meningkatkan kapasitas mereka atau modal usaha yang bisa menjadi investasi berkelanjutan. Seperti yang disampaikan oleh WRSE berikut ini:

"Program/pelatihan tidak bisa, tapi kalau bantuan yang mau." (WRSE/04, 2016)

Bahkan salah satu WRSE membuat pernyataan yang lebih ekstrim,yaitu:

"Pemerintah tidak perlu membuat program, membuat bantuan saja yang pasti dan tepat sasaran." (WRSE/05, 2016)

Keengganan WRSE terhadap program pelatihan karena WRSE merasa tidak memiliki waktu senggang :

"Kalau pelatihan saya tidak mau mbak, tidak bisa, waktu juga tidak ada.” (WRSE/14, 2016)

Buvinic (1997) melalui penelitiannya bahwa salah satu hambatan kebanyakan wanita di seluruh dunia untuk meningkatkan perekonomian mereka, adalah tidakmemiliki waktu senggang untukberinvestasi dalam pekerjaan tambahan untuk meningkatkan pendapatan mereka. Hal ini terkait dengan peran reproduktif yang menjadi tanggung-jawab kaum perempuan, disamping peran produktif WRSE sebagai kepala rumah tangga

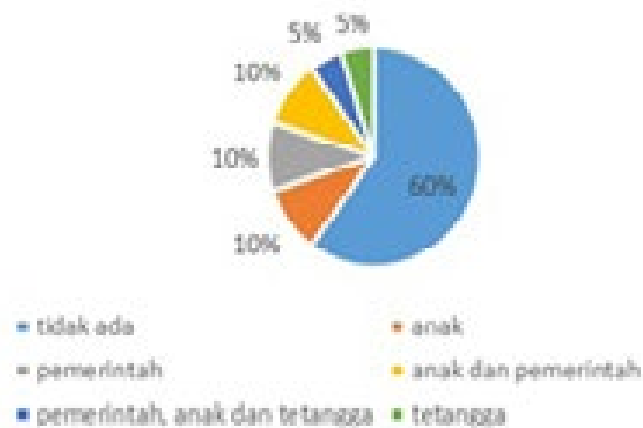

Sumber: Data Primer, 2016

Gambar 5. Hambatan-hambatan yang dialami Oleh WRSE di Desa Tepusen

yang harus menghidupi keluarganya.

Rendahnya kesadaran WRSE akan pentingnya program peningkatan kapasitas untuk mengentaskan mereka dari kemiskinan dapat juga disebabkan oleh rendahnya tingkat pendidikan yang memberikan pengaruh terhadap pola pikir mereka. Seperti yang dideskripsikan oleh Gambar 2, yaitu 60\% pendidikan tertinggi WRSE di desa ini adalah lulus Sekolah Dasar, sedangkan $40 \%$ sudah pernah mengenyam pendidikan dasar namun tidak sampai lulus.

Faktor penghambat yang ketiga terkait dengan usia WRSE di desa ini. Saat ini, WRSE di desa ini hanya $5 \%$ yang berusia di bawah 40 tahun. $10 \%$ pada rentang usia 41 - 50 tahun, $50 \%$ pada rentang usia 51 - 60 tahun, dan 35\% berusia di atas usia 60 tahun. Artinya, pada umumnya WRSE di desa ini usianya tidak lagi muda, sehingga upaya untuk meningkatkan kemauan dan kemampuan mereka melalui programprogram pelatihan tidak lagi diminati mengingat usia mempengaruhi tenaga dan motivasi mereka untuk hidup lebih baik. Hal ini diungkapkan oleh salah satu WRSE:

Saya ingin program renovasi rumah saja, kalau usaha sudah tidak mampu lagi badannya. (WRSE/08, 2016).

Selanjutnya jika dilihat dari jumah anggota keluarga yang menjadi tanggungan WRSE di desa ini, $50 \%$ dari WRSE yang ada di desa ini tidak lagi memiliki tanggungan, 35\% memiliki 1 tanggungan dan 10\% dengan tanggungan 2-3, dan 5\% memiliki 8 tanggungan (Gambar 7). Tanggungan WRSE umumnya adalah anak kandung mereka, selain itu orang tua atau cucu mereka.

Dari informasi tersebut, dapat disimpulkan bahwa $50 \%$ WRSE di desa ini tidak lagi harus menghidupi anggota keluarganya, bahkan 20\% dari mereka sudah mendapatkan bantuan dari anak-anak mereka yang sudah bekerja. Hal tersebut juga menurunkan motivasi mereka untuk hidup lebih baik melalui program. Sebaliknya, jika mereka masih memiliki tanggungan, mereka harus bekerja keras sepanjang hari untuk menghidupi anggota keluarganya selain menjalankan peran reproduktif mereka, sehingga mereka tidak 
memiliki waktu senggang untuk melakukan hal lain.

Faktor penghambat terakhir adalah terbatasnya akses WRSE pada lembaga finansial untuk mempermudah mereka mendapatkan modal untuk mengembangkan usaha. Dari total WRSE yang ada di desa ini, hanya 5\% WRSE yang menyebutkan bank sebagai salah satu pihak yang mendukungnya (Tabel 1).

Naidoo \& Hilton (2006) menjelaskan, hambatan dalam mengakses keuangan, termasuk kurangnya melek finansial bersumber dari rendahnya pendidikan, kurangnya kemapanan finansial yang bersumber dari rendahnya pendapatan, terbatasnya pemanfaatan networking, serta prasangka budaya dan stereotip negatif terhadap perempuan sebagai pengusaha.

Sejalan dengan kesimpulan Buvinic (1997), kebanyakan wanita di seluruh dunia, menghadapi hambatan yang sama untuk meningkatkan perekonomian mereka, yaitu: tidak memiliki waktu senggang untuk berinvestasi dalam pekerjaan tambahan untuk meningkatkan pendapatan, kurangnya akses kredit komersial, dan pelatihan keterampilan untuk perempuan yang sebagian besar ketrampilan berupah rendah.

Rekomendasi strategi untuk WRSE adalah dengan telah banyak dilakukan program dan proyek yang berusaha "memerangi" dilakukan kemiskinan, baik yang diselenggarakan oleh pemerintah maupun masyarakat. Namun belum juga membuahkan hasil yang diharapkan. Permasalahan tersebut muncul karena minimnya pendekatan yang melibatkan kaum miskin dalam proses perencanaan program maupun dalam pelaksanaannya. Orang miskin dianggap tidak memiliki potensi dan kekuatan sehingga mereka dianggap sebagai objek. Pendekatan ini secara tidak langsung memperparah kondisi orang miskin, karena mengakibatkan ketergantungan baik secara ekonomi, sosial, maupun politik.

Di sisi lain, Sukidjo, dkk. (2014) menyimpulkan bahwa kemiskinan pada dasarnya merupakan kondisi ketidakberdayaan masyarakat dalam memenuhi kebutuhan kehidupannya karena ketidakadilan yang bersifat multidimensi baik politik, ekonomi, sosial, budaya dan teknologi. Oleh sebab itu, untuk mengatasi kemiskinan perlu dilakukan secara komprehensif dan menyeluruh yakni melalui program pemberdayaan ekonomi, sosial dan budaya.

Untuk merumuskan rekomendasi mengentaskan WRSE dari kemiskinan tidaklah mudah karena perlu dipahami bahwa mengurangi tingkat kemiskinan dan jumlah wanita miskin tidak dapat dicapai hanya dengan program yang berorientasi peningkatan ekonomi semata. Beban ganda perempuan yang harus mengurus rumah, merawat anggota keluarganya membuat perempuan tidak memiliki banyak waktu untuk melakukan aktifitas produktif apalagi mengikuti pelatihan untuk meningkatkan kapasitas mereka.

Dari pembahasan mengenai faktor penghambat program pengentasan kemiskinan bagi WRSE dapat disimpulkan bahwa pemberian modal usaha dan program pelatihan ketrampilan ternyata tidaklah cukup. Terlepas dari rendahnya tingkat pendidikan yang mempengaruhi pola pikir WRSE, sebagian besar WRSE di desa ini menginginkan bantuan dana untuk meringankan penghidupan mereka sebagai strategi mengentaskan mereka dari kemiskinan. Sejalan dengan kesimpulan Sukidjo, dkk. (2014) bahwa kemiskinan pada dasarnya merupakan kondisi ketidakberdayaan masyarakat dalam memenuhi kebutuhan kehidupannya karena ketidakadilan yang bersifat multidimensi baik politik, ekonomi, sosial, budaya dan teknologi. Kondisi ini yang kemudian disebut dengan ketidakberdayaan atau powerless. Menurut Hill dalam Zastrow (1995), ketidakberdayaan tersebut terutama banyak dialami oleh kaum perempuan (Feminization of Poverty). Oleh sebab itu, diperlukan agenda besar untuk menghapus atau meminimalkan ketidakadilan yang memicu ketidakberdayaan perempuan.

Strategi untuk mengentaskan WRSE dari Kemiskinan adalah pendidikan formal, WRSE yang berstatus gadis atau janda yang dulunya menikah muda dan harus meninggalkan bangku sekolah lalu kemudian menjadi janda di usia belia/sekolah diberikan bantuan/ beasiswa untuk meraih ijazah pendidikan formal (misal melalui sekolah atau kejar paket) yang kelak bermanfaat untuk meningkatkan kehidupannya, yaitu membuka peluang WRSE untuk bekerja pada sektor formal.

Pendidikan informal/pelatihan untuk meningkatkan kapasitas bagi WRSE usia muda. Program pendampingan spiritual/psikologis bagi WRSE. Tidak hanya di Kabupaten Temanggung, program-program pendampingan bagi WRSE masih seputar program peningkatan perekonomian mereka. Dari hasil penelitian diperoleh hasil bahwa 90\% WRSE merasa sedih dan kesulitan saat menjadi WRSE. Oleh sebab itu, WRSE usia tua maupun belia membutuhkan pendampingan spiritual maupun psikologis untuk menjalani kehidupannya.

Membuka akses WRSE pada microfinance (keuangan mikro). Menurut Brooks (2013) dalam Othman (2015), keuangan mikro mengacu pada berbagai layanan keuangan, termasuk pinjaman, tabungan dan asuransi, yang tersedia untuk pengusaha miskin dan pemilik usaha kecil yang tidak memiliki jaminan dan tidak akan dinyatakan memenuhi syarat untuk pinjaman bank standar. Keuangan mikro sangat berhubungan untuk mencapai kemakmuran bersama karena memungkinkan segmen penduduk miskin untuk mengakses ke layanan keuangan untuk memperoleh kebebasan finansial dengan kegiatan yang meningkatkan penghasilan, seperti untuk mendorong kegiatan kewirausahaan skala kecil, sehingga mengurangi ketidaksetaraan kesejahteraan sosioekonomi pada suatu negara.

UNDP (2008) dalam Bundlender (2005) membuktikan, dengan meningkatkan akses perempuan terhadap keuangan mikro akan memperluas manfaat; 
bukan hanya untuk kesejahteraan mereka, tetapi juga untuk kesejahteraan keluarga mereka, masyarakat di mana mereka tinggal dan untuk masyarakat luas.

Namun demikian, program-program tersebut tidak akan berhasil jika WRSE tidak mendapatkan bantuan dalam menopang penghidupannya sehingga waktunya tersita untuk menghidupi dan merawat keluarganya. Oleh sebab itu, meski terkesan menimbulkan ketergantungan, namun programprogram instant sangat diperlukan baik untuk WRSE usia muda maupun tua. Bantuan dana untuk menopang penghidupan WRSE termasuk dana kesehatan.

Dana pendidikan, dana gizi untuk anak-anak WRSE. Hal tersebut selain untuk meringankan beban WRSE, pendidikan merupakan upaya untuk memutus rantai kemiskinan. Seperti yang menjadi kesimpulan Budlender (2005) pada penelitiannya di Afrika Selatan, secara umum untuk bantuan dana untuk membantu anak-anak perempuan miskin tampaknya menjadi yang langkah paling efektif.

Tulisan di bawah Gambar 8. sangat penting untuk diperhatikan:

"Will her granddaughters have it easier?"

"Akankah cucunya hidup lebih mudah?"

Mengentaskan WRSE dari kemiskinan bukanlah pekerjaan tunggal, yang lebih penting adalah memutus rantai kemiskinan, sehingga kehidupan sulit yang mereka jalani sebagai WRSE tidak akan diulang oleh anak cucu mereka.

Membentuk jaringan pendukung WRSE, Tabel 1 menunjukkan keluarga merupakan pihak pendukung yang paling sering disebutkan oleh WRSE, diikuti pemerintah, tetangga dan pihak lain/bank. Oleh sebab itu perlu dilakukan upaya edukasi pada keluarga, masyarakat maupun instansi agar dapat bekerjasama berkontribusi membantu WRSE melalui dukungan moral, perlakuan yang tepat, maupun bantuan lainnya. Disamping itu, Dinas Sosial sebagai pengampu WRSE dapat lebih meningkatkan kerjasama dengan SKPD lainnya maupun dengan pihak lain (bank, CSR perusahaan) untuk memberikan bantuan maksimal pada WRSE.

Pelibatan WRSE dalam dalam merumuskan strategi mengentaskan mereka dari kemiskinan. Pelibatan secara langsung mungkin tidaklah mudah, namun aspirasi dan kondisi spesifik mereka mengenai nilai-nilai sosial yang menempatkan mereka pada kedudukan yang tidak menguntungkan perlu digali untuk merumuskan strategi yang paling tepat.

\section{KESIMPULAN}

Faktor-faktor yang menyebabkan wanita menjadi WRSE di desa ini adalah perceraian atau kematian suami, tingkat pendidikan rendah, pekerjaan dengan gaji rendah.Upaya-upaya yang telah dilakukan Dinsos untuk mengatasi WRSE yaitu dana ternak, pelatihan pembuatan kue dan pelatihan sulam pita. Faktor-faktor penghambat dalam upaya pengentasan WRSE adalah minimnya waktu senggang, rendahnya tingkat pendidikan, usia WRSE, jumlah tanggungan, terbatasnya akses finansial Strategi yang dapat direkomendasikan untuk mengentaskan WRSE dari kemiskinan: akses pada pendidikan formal, pelatihan untuk meningkatkan kapabilitas, bantuan dana untuk penghidupan WRSE dan anak-anak WRSE, membuka akses pada keuangan mikro, pendampingan spiritual/ psikologis, memperkuat jaringan pendukung WRSE, dan pelibatan WRSE dalam merumuskan strategi mengentaskan mereka dari kemiskinan.

\section{UCAPAN TERIMA KASIH}

Ucapan terima kasih peneliti ucapkan kepada Fakultas Geografi UGM yang telah rutin mengalokasikan dana penelitian dosen setiap tahunnya. Ucapan terimakasih yang kedua peneliti ucapkan untuk Dinsos Kabupaten Temanggung, Perangkat Desa dan masyarakat Desa Tepusen (WRSE), dan Pemerintah Kabupaten Temanggung yang telah membantu memberikan data maupun informasi yang dibutuhkan pada penelitian ini. Peneliti juga mengucapkan kepada asisten yang telah membantu penelitian ini: Ika Agustina, Lusia Charisma, Rahma Fitri, dan Amina Raisa dan juga pada berbagai pihak yang telah membantu dan mendukung penelitian ini, yang tidak bisa peneliti sebut satu persatu.

\section{DAFTAR PUSTAKA}

Bebbington, A. (2003). Global networks and local developments: Agendas for development geography. Tijdschrift voor economische en sociale geografie, 94(3), 297-309.

Budlender, Debbie. (2005). Women and Poverty. Agenda: Empowering Women for Gender Equity, 64, 30-36.

Buvinic, M., \& Gupta, G.R. (1997). Female-headed households and female maitained families: Are they worth targeting to reduce poverty in developing countries?: Economic Development and Cultural Change, 45, 259-280.

Christie, Pam and Gordon, Adele. (1992). Politics, Poverty and Education in Rural South Africa: British Journal of Sociology of Education, 13 (4), 399-418.

Fausia, L. dan Prasetyaningsih, N. (2005). Gender dalam Kawasan DAS Citanduy. Kajian Aktifitas Reproduktif dan Produktif Perempuan dalam Sumberdaya Alam: Working Paper Proyek Desentralisasi Pengelolaan dan Sistem Tata Pamong Sumberdaya Alam Kasus DAS Citanduy

Flato, Martin, Mutarak, R., Pelser, A. (2016). Women, Weather, and Woes. The Triangular Dynamics of Female-Headed Households. Economic Vulnerability, and Climate Variability in South Africa: World Development, Vol. xx, pp. xxx-xxx. 
Harini, Rika dan Listyaningsih, Umi. (2000). Perubahan Strategi Bertahan Hidup Wanita Kepala Rumah Tangga di Masa Krisis (Studi Kasus Kecamatan Umbul Harjo Daerah Istimewa Yogyakarta): Majalah Geografi Indonesia, 15 (1), 47 - 62.

Idris, N.A.H., Selvaratnam, D.P. (2012). Program Pembasmian Kemiskinan Dalam Kalangan Ibu Tunggal: Analisis Penyertaan Dan Keberkesanan: Prosiding Persidangan Kebangsaan Ekonomi Malaysia. VII (1), 248 - 259, ISSN: 2231-962X

Naidoo, Sharda, and Anne Hilton. "Access to finance for women entrepreneurs in South Africa." Pretoria: International Finance Corporation/Department of Trade and Industry/FinMark Trust (2006).

Nihayah, Ana Zahrotun. (2015). Pengaruh Program Simpan Pinjam Kelompok Perempuan Terhadap Pendapatan Usahamikro Kecil Dan Poverty Reduction Dalam Perspektif Ekonomi Islam (Studi Kasus PNPM Mandiri Perdesaan Kecamatan Bangilan, Tuban): Jurnal Ekonomi dan Hukum Islam, 5 (2), 1 - 24.

Othman, Muhamad Badri. (2015). Role of women in achieving shared prosperity. An impact study of Islamic microfinance in Malaysia: Procedia - Social and Behavioral Sciences, 211, 1043 - 1048.
Sukidjo, Sihono, T., Mustofa. (2014). Pemberdayaan Kelompok Perempuan Dalam Pengentasan Kemiskinan Berbasis Pengembangan Usaha Mikro: Jurnal Economia, 10 (1), 1-10.

Suman, Agus. (2007). Pemberdayaan Perempuan, Kredit Mikro, dan Kemiskinan: Sebuah Studi Empiris. Jurnal Menejemen dan Kewirausahaan, 9 (1), 62-72.

Zastrow, Charles. (1982). Introduction to Social Welfare Institutions Social Problems, Services, and Current Issues. The Dorsey Press. USA

Dinas Sosial. (2015). Pedoman Umum Pemberdayaan Keluarga, diambil dari http://www.kemsos.go.id/ modules.php? name $=$ glosariumkesos\&letter $=$ w, diakses pada tanggal 14 Maret 2016. 